\title{
Front Matter: Volume 11806
}

, "Front Matter: Volume 11806," Proc. SPIE 11806, Quantum Nanophotonic Materials, Devices, and Systems 2021, 1180601 (17 August 2021); doi: $10.1117 / 12.2606470$

SPIE Event: SPIE Nanoscience + Engineering, 2021, San Diego, California, United SPIE. States 


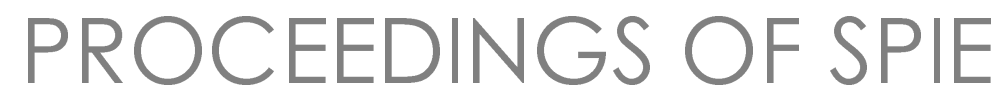

\section{Quantum Nanophotonic Materials, Devices, and Systems 2021}

Cesare Soci

Matthew T. Sheldon

Mario Agio

Editors

1-5 August 2021

San Diego, California, United States

Sponsored and Published by

SPIE 
The papers in this volume were part of the technical conference cited on the cover and title page. Papers were selected and subject to review by the editors and conference program committee. Some conference presentations may not be available for publication. Additional papers and presentation recordings may be available online in the SPIE Digital Library at SPIEDigitalLibrary.org.

The papers reflect the work and thoughts of the authors and are published herein as submitted. The publisher is not responsible for the validity of the information or for any outcomes resulting from reliance thereon.

Please use the following format to cite material from these proceedings:

Author(s), 'Title of Paper," in Quantum Nanophotonic Materials, Devices, and Systems 2021, edited by Cesare Soci, Matthew T. Sheldon, Mario Agio, Proc. of SPIE 11806, Seven-digit Article CID Number (DD/MM/YYYY); (DOI URL).

ISSN: 0277-786X

ISSN: 1996-756X (electronic)

ISBN: 9781510644502

ISBN: 9781510644519 (electronic)

Published by

SPIE

P.O. Box 10, Bellingham, Washington 98227-0010 USA

Telephone +1 3606763290 (Pacific Time)

SPIE.org

Copyright @ 2021 Society of Photo-Optical Instrumentation Engineers (SPIE).

Copying of material in this book for internal or personal use, or for the internal or personal use of specific clients, beyond the fair use provisions granted by the U.S. Copyright Law is authorized by SPIE subject to payment of fees. To obtain permission to use and share articles in this volume, visit Copyright Clearance Center at copyright.com. Other copying for republication, resale, advertising or promotion, or any form of systematic or multiple reproduction of any material in this book is prohibited except with permission in writing from the publisher.

Printed in the United States of America by Curran Associates, Inc., under license from SPIE.

Publication of record for individual papers is online in the SPIE Digital Library.

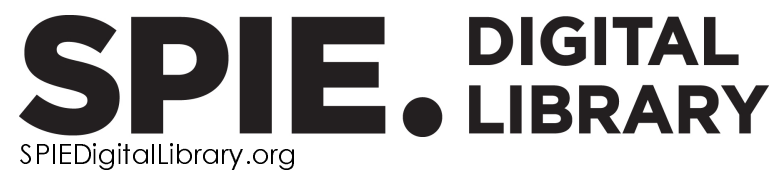

Paper Numbering: A unique citation identifier (CID) number is assigned to each article in the Proceedings of SPIE at the time of publication. Utilization of CIDs allows articles to be fully citable as soon as they are published online, and connects the same identifier to all online and print versions of the publication. SPIE uses a seven-digit CID article numbering system structured as follows:

- The first five digits correspond to the SPIE volume number.

- The last two digits indicate publication order within the volume using a Base 36 numbering system employing both numerals and letters. These two-number sets start with $00,01,02,03,04$, $05,06,07,08,09,0 A, 0 B \ldots$ OZ, followed by 10-1Z, 20-2Z, etc. The CID Number appears on each page of the manuscript. 


\section{Contents}

QUANTUM NANOPHOTONIC SYSTEMS

$1180604 \quad$ Free-space confocal magneto-optical spectroscopies at milliKelvin temperatures (Invited Paper) [1 1806-3]

1180607 Integration of colloidal quantum dots with nanophotonic circuits [1 1806-15]

MATERIAL PLATFORMS FOR QUANTUM PHOTONIC DEVICES

11806 OD A nanophotonic interface for tin-vacancy spin qubits in diamond [11806-10]

QUANTUM PHOTONIC DEVICES FOR SIMULATIONS, METROLOGY, ETC.

11806 OL Generation of high-dimensional photonic entanglement [1 1806-23]

11806 OM Preservation of spatial entanglement in surface plasmon polaritons (Invited Paper) [1 1806-26]

QUANTUM LIGHT SOURCES

11806 ON Quantum speed-ups in reinforcement learning [1 1806-18]

11806 OS Si waveguide-integrated superconducting nanowire single photon detectors with arrayed waveguide grating (Invited Paper) [1 1806-27]

POSTER SESSION

11806 OU Double-well effective potential in a linear Paul trap with end-cap electrodes [1 1806-4] 
Proc. of SPIE Vol. 11806 1180601-4

\section{Downloaded From: https://www.spiedigitallibrary.org/conference-proceedings-of-spie on 26 Apr 2023
Terms of Use: https://www.spiedigitallibrary.org/terms-of-use}

